Anna Jaroszewska

Uniwersytet Warszawski

a.jaroszewska@uw.edu.pl

\title{
KURS JĘZYKA OBCEGO W ROTACJI TRANSGRANICZNEJ - OPTYMALNY CZY UTOPIJNY MODEL KSZTALCENIA?
}

\section{Language course based on foreign exchange: an optimum or utopian learning model?}

\begin{abstract}
Appreciating the complexity of glottodidactic system, the viability of objectives as well as the multiplicity of foreign language teaching and learning methods, the author of this paper attempts to form a more precise definition of a relatively new language learning concept which is the language course based on foreign exchange.
\end{abstract}

Keywords: Language teaching/learning, glottodidactics, communication competence, intercultural competence, language course based on foreign exchange

Słowa kluczowe: nauczanie/uczenie się języków obcych, glottodydaktyka, kompetencja komunikacyjna, kompetencja międzykulturowa, kurs $w$ rotacji transgranicznej

\section{Tło rozważań}

Ekonomiczne i geopolityczne problemy ostatnich lat otwierają zupełnie nową kartę w historii stosunków międzynarodowych i międzykulturowych - coraz bliższych, pełnych napięć, dla jednych naznaczonych obawami, innym przynoszących nadzieję, z pewnością nieuniknionych. Na południu Europy dzieje się tak choćby za sprawą zapaści finansowej Grecji, która wstrząsnęła posadami Unii Europejskiej, na północy przez ponadprzeciętne aspiracje i niezdecydowanie Wielkiej Brytanii, jakie ta manifestuje względem europejskiej Wspólnoty, na 
jej wschodnich rubieżach przez zaogniający się konflikt ukraińsko-rosyjski, zaś poza jej granicami głównie w wyniku Arabskiej Wiosny Ludów prowadzącej do politycznych i religijnych podziałów w Afryce Północnej i na Półwyspie Arabskim, czego negatywnym skutkiem stała się militarna ekspansja tzw. Państwa Islamskiego oraz wzmagająca się wraz z nią fala migracyjna, która zalewa właśnie Europę. Pomimo tych i zapewne jeszcze wielu innych zawirowań, zjawiska globalizmu i unifikacji zataczają coraz szersze kręgi. Stają się immanentną częścią już nie tylko większości państw starego kontynentu i zbudowanych na fundamentach demokracji kluczowych gospodarek pozaeuropejskich, np. amerykańskiej, kanadyjskiej czy australijskiej, lecz coraz częściej zmieniają zasady funkcjonowania ustrojów centralnie sterowanych, do niedawna uznawanych za hermetyczne i niepodatne na wpływy Świata Zachodu - przykładami najbardziej wyrazistymi będą tu zapewne Chińska Republika Ludowa czy kontrowersyjna w sposobie uprawiania demokracji Federacja Rosyjska.

Zmiany te są bezpośrednim bądź pośrednim następstwem militarnych podbojów i migracji ludności, otwarcia granic terytorialnych, nasilających się kontaktów handlowych i rozwoju korporacji międzynarodowych, transgranicznych sojuszy (gospodarczych, politycznych i wojskowych), przede wszystkim zaś stanowią konsekwencję postępu cywilizacyjnego przejawiającego się m.in. w rozwoju i upowszechnieniu środków transportu oraz nowych technologii, ten bowiem sukcesywnie dociera do najdalszych zakątków Ziemi, ułatwiając, a jednocześnie intensyfikując procesy komunikowania się ludzi i relacje między nimi. Poza przeobrażeniami strukturalnymi, do jakich prowadzą, czynniki te dobitnie wpływają również na obraz współczesnych społeczeństw, które, podobnie jak systemy gospodarcze poszczególnych państw, stają się coraz bardziej otwarte, a przez to kulturowo złożone. U podstaw otwartości na inność kulturową leżą dziś jednak nie tylko zakorzenione w tradycjach liberalne usposobienie danej nacji, psychospołeczne i typowo komunikacyjne przygotowanie tworzących ją jednostek oraz splot wyżej wymienionych okoliczności geopolitycznych i gospodarczych. W znaczniej mierze otwartość ta jest także pokłosiem poprawności politycznej, która, niegdyś przyjmująca postać politycznego czy medialnego dyskursu i realizowana z zamysłem poszanowania godności ludzkiej, zwłaszcza ciemiężonych mniejszości etnicznych, obecnie staje się coraz częściej kartą przetargową służącą do osiągnięcia przewagi politycznej i zaspokajania mniej szczytnych celów, często kosztem ogółu.

Rozkwitający na tym tle językowo-kulturowy pluralizm, tak gruntownie pielęgnowany przez agendy unijne, rodzi tym samym nie tylko szanse, lecz i zagrożenia. Te drugie zaś, wynikające m.in. z nadinterpretacji zasad funkcjonowania społeczeństwa demokratycznego oraz z przeszacowania jego możliwości w kontekście wspomagania innych, niedemokratycznych ustrojów państwowych, 
dawno już przestały dotyczyć wyłącznie multikulturowego ogniska domowego i specyficznych społecznych relacji na obszarze wielo- lub innokulturowych dzielnic, z którymi można się dziś zetknąć, przemierzając europejskie stolice. W niebywałym tempie przeradzają się one w makroproblemy dotykające coraz większej liczby państw i narodów, dotychczas - wydawałoby się - ideologicznie i kulturowo stabilnych, jak choćby Szwecja, Niemcy, Francja czy Wielka Brytania. Problemy, z którymi państwa te borykają się na co dzień, w dalszym ciągu bagatelizowane lub utajniane, niestety swoje źródło znajdują w szeroko pojmowanym kulturowym i ekonomicznym rozwarstwieniu, którego nie udało się dotychczas zniwelować mimo licznych strategii i programów adaptacyjnych, pomocowych i edukacyjnych - kierowanych zarówno do ludności napływowej, jak i rdzennych obywateli. Trudno też nie zauważyć, że problemy te niebawem mogą dotyczyć także Polski i Polaków. Nie dziwi zatem fakt, że nauczaniu języków obcych oraz osadzonemu w tym procesie międzykulturowemu kształceniu zaczęto przypisywać szczególne, strategiczne już znaczenie: społeczno-kulturowe, gospodarcze, polityczne. $Z$ tego powodu także próby poszukiwania nowych rozwiązań dydaktyczno-metodycznych w tym zakresie należy uznać za pożądane. Pozwalają one bowiem zdywersyfikować wachlarz dostępnych możliwości kształcenia, które winno być dostosowane do konkretnych celów i potrzeb - w głównej mierze manifestowanych przez samych uczniów, stanowiących przecież niezwykle barwną mozaikę osobowości i kultur, niekiedy stojących w jawnej opozycji względem siebie.

Pozostawiając czytelnikowi ocenę problemów natury ideologicznej, które podczas debat na temat wielo- i międzykulturowości były i zapewne jeszcze wielokrotnie będą przywoływane (por. Jaroszewska, 2015), za cel niniejszego artykułu obrano w tym kontekście wstępną prezentację koncepcji jednego z takich rozwiązań - kursu języka obcego w rotacji transgranicznej. W takim samym, a być może nawet w większym stopniu, co kurs tradycyjny, może on służyć kształtowaniu u uczących się językowej kompetencji komunikacyjnej oraz kompetencji międzykulturowej. Jest to jednak możliwe pod pewnymi warunkami i w szczególnych okolicznościach, które same w sobie stanowią o zapotrzebowaniu i zasadności takiej formuły kształcenia lub wręcz przeciwnie - o jej utopijnym charakterze.

\section{Hipoteza robocza}

Kwerenda oferty programowej wykonana na potrzeby niniejszego artykułu - w tym przypadku dotycząca polskich szkół językowych oraz działających na polskim rynku edukacyjnym instytutów języków i kultur narodowych, takich jak: niemiecki Goethe-Institut, austriacki Österreich Institut, brytyjski British Council, francuski Alliance Française, rosyjski Pushkin Institute, hiszpański Instituto 
Cervantes czy też włoski Instituto Italiano di Cultura - wykazała, że idea kursu języka obcego w rotacji transgranicznej nie została dotychczas wdrożona do praktyki. Trudno też orzec, by cieszyła się ona zainteresowaniem świata nauki, mediów czy środowisk nauczycielskich. Nie można jej przecież kojarzyć z niezliczoną wręcz liczbą i zróżnicowaniem programowo niepowiązanych wyjazdowych zagranicznych kursów językowych, pomimo że to właśnie tego typu kursy mogą stanowić bazę dla realizacji omawianego przedsięwzięcia. Kursy o charakterze wyjazdowym w znacznym stopniu odbiegają bowiem pod względem organizacji zajęć dydaktycznych od kursów tradycyjnych - lokalnych, prowadzonych w systemie klasowo-lekcyjnym. Poza programem zajęć typowo językowych, proponują uczącym się języka obcego - przynajmniej według opisów zamieszczanych w prospektach reklamowych - bogaty program krajo- i kulturoznawczy, przede wszystkim zaś możliwość „zanurzenia się” w naturalnym otoczeniu społeczno-kulturowym właściwym dla kraju czy regionu, w którym nauczany język jest językiem pierwszym bądź co najmniej urzędowym. Nie ulega też wątpliwości, że kursy tego typu stwarzają szansę na podjęcie przez uczących się międzykulturowego dialogu - nie tylko z rodzimymi użytkownikami danego języka, ale i z innymi kursantami, bardzo często reprezentującymi różne nacje, języki, wyznania, obyczaje czy światopoglądy, w dużej mierze uwarunkowane ich pochodzeniem. Tymczasem kursy języków obcych w tradycyjnej formule cechuje zazwyczaj, choć nie zawsze, monokulturowy kapitał społeczny, któremu w omawianym kontekście mimo wszystko trzeba przypisać niższą wartość poznawczą.

Można zatem przyjąć, że idea kursu języka obcego w rotacji transgranicznej jest dostępna niemal na wyciągnięcie ręki, jednak pozostaje niezauważona i nienazwana, a przez to w praktyce niezagospodarowana, co mogłyby zmienić włączenie jej w nurt debaty popularnonaukowej poświęconej problematyce wielojęzyczności i międzykulturowości, idąca w ślad za tym jej właściwa oprawa medialna, a ponadto nowy model organizacyjny i marketingowy zagranicznych kursów języków obcych. Brak dopracowanej oferty programowej, informacji i zachęty kierowanej w stronę uczących się bądź potencjalnych uczestników tego typu kursów przesądza bowiem o tym, że, decydując się na udział w kursie wyjazdowym, wyboru oferty dokonują oni głównie na podstawie przesłanek ekonomicznych, renomy organizatora, treści programowych oraz destynacji wynikającej z obszaru wpływów danego języka. Są to przesłanki naturalne, powiązane głównie z indywidualnymi możliwościami, jak również potrzebami poznawczymi. Te ostatnie najczęściej koncentrują się wokół optymalnych możliwości poznania języka będącego przedmiotem nauczania i rodzimej dla niego kultury. Zatem chęć nauczenia się języka angielskiego najczęściej skłania do wyboru kursu językowego w Anglii, Irlandii czy Stanach Zjednoczonych, 
dla języka niemieckiego najdogodniejszym wydaje się kurs w Niemczech bądź innych krajach niemieckiego obszaru językowego, język francuski najlepiej z kolei studiować we Francji, zaś rosyjski w Rosji itd., zwłaszcza że w każdym z tych krajów najpełniej można zetknąć się z rdzenną kulturą ich mieszkańców. Jest to tok rozumowania jak najbardziej słuszny. Uczący się języka obcego, którzy decydują się na wyjazdową formułę kształcenia, bardzo często zapominają jednak - podobnie jak wspomniani organizatorzy kursów językowych - o złożonym charakterze społeczeństw tych krajów, o tym, że panuje w nich językowo-kulturowy pluralizm, że egzystują w nich inne nacje, różne grupy etniczne i wyznaniowe, które wnoszą istotny wkład w całościowy obraz tych społeczeństw i, co istotne, które równie dogłębnie można poznać i zrozumieć także w innych rejonach Świata, niekoniecznie tam, gdzie mówi się w języku będącym przedmiotem nauczania.

Ucząc się danego języka obcego i poznając wyłącznie kulturę autochtonów, czyli rodzimych użytkowników tego języka, w pewnym sensie sami kursanci zwykle nieświadomie zubażają proces kształtowania własnej kompetencji międzykulturowej. Na ten problem zwróciła uwagę międzynarodowa grupa seniorów uczestnicząca w jednym z takich zagranicznych i jednocześnie międzykulturowych kursów języka niemieckiego, jaki w 2007 roku zorganizował Goethe-Institut w jednym z miast Badenii-Wirtembergii (por. Jaroszewska, 2013: 168 i n.). I to właśnie ich spostrzeżenia - osób z niezwykle bogatym bagażem doświadczeń międzykulturowych, w tym w zakresie kształcenia obcojęzycznego - stały się przyczynkiem do tego, by kwestię nauki języków obcych w ramach rotacji transgranicznej poruszyć na forum specjalistów.

\section{Próba definicji}

Językowy kurs w rotacji transgranicznej jest specyficzną formą nauczania/uczenia się języka obcego bądź języków obcych, która przejawia się w cyklicznym, metodycznie i organizacyjnie zaplanowanym procesie dydaktyczno-wychowawczym polegającym - w uproszczeniu - na przekazywaniu przez nauczyciela/zgłębianiu przez uczniów tajników wiedzy językowej i kulturowej, w naturalny sposób dla nich obcych, a stanowiących przedmiot ich zainteresowania. Proces ten jest realizowany podczas wyjazdów zagranicznych - inaczej: podczas kursów pobytowych, np. wakacyjnych, intensywnych, zawodowych itd. - z zachowaniem zasady rotacji, a więc każdorazowej zmiany miejsca organizacji kursu dla kolejnego poziomu kompetencyjnego. Zmiana otoczenia kulturowego, w którym prowadzone są zajęcia językowe, ma na celu nie tyle optymalizację warunków kształcenia ściśle określonych kompetencji lingwistycznych (leksykalnej, gramatycznej, semantycznej, fonologicznej, ortograficznej, ortoepicznej), to 
bowiem jest możliwe i wskazane niezależnie od tego, czy kurs ma charakter wyjazdowy, stacjonarny czy też jest realizowany za pośrednictwem różnego rodzaju mediów. Zmiana taka - tu utożsamiana z rotacją - powinna raczej zapewniać dogodne warunki dla rozwoju, także w praktyce, szeregu innych kompetencji, które wraz przygotowaniem językowym będą wyrażać poziom kompetencji międzykulturowej uczącego się - później aktywnego użytkownika danego języka, ale też „obywatela Świata”, potrafiącego współżyć z innymi ludźmi w rozprzestrzeniającym się kulturowym tyglu. Chodzi zatem przede wszystkim o wspomaganie rozwoju jego kompetencji ogólnych, na które składają się (za: Rada Europy, 2003: 94 i n.):

1. wiedza deklaratywna (savoir): wiedza o świecie, wiedza społecznokulturowa oraz wrażliwość interkulturowa;

2. wiedza proceduralna (savoir-faire): umiejętności praktyczne oraz interkulturowe;

3. potencjał osobowościowy (savoir-être);

4. umiejętność uczenia się (savoir-apprendre): wrażliwość językowa i komunikacyjna, ogólna wrażliwość i sprawność fonetyczna, techniki uczenia się, umiejętności heurystyczne,

a których posiadanie oraz stały rozwój umożliwia realizację programu kształtowania równie ważnych w procesie komunikacji obcojęzycznej i międzykulturowej kompetencji socjolingwistycznych oraz pragmatycznych (por. Byram, 1997; Bolten, 2007).

To, co odróżnia kurs języka obcego w rotacji transgranicznej od innych kursów o charakterze wyjazdowym, również zagranicznych, to rozwinięty program nauczania międzykulturowego bazujący na przekazywaniu wiedzy teoretycznej, ćwiczeniach laboratoryjnych oraz realnym kontakcie z przedstawicielami innych kultur. Z tym jednak zastrzeżeniem, że chodzi tu nie tylko o możliwie pełne zaznajomienie się z kulturą Niemców, w przypadku nauki języka niemieckiego, czy Francuzów, gdy przedmiotem nauczania jest język francuski itd. Celem takiego kursu jest umożliwienie kursantom wglądu w całą mozaikę kulturową społeczeństwa niemieckiego, francuskiego i innych, a więc stworzenie okazji do poznania - poprzez obserwację i bezpośredni kontakt - także tworzących je grup etnicznych: rdzennych i napływowych. W dużym uproszczeniu można zatem przyjąć, że cechą charakterystyczną takiego kursu winna być wspomniana rotacja, a więc zmienna lokalizacja - najpierw w obrębie danego obszaru językowego, a następnie poza tym obszarem, nie tylko w Niemczech, Austrii, Szwajcarii czy Luksemburgu, gdy przedmiotem nauczania jest język niemiecki, ale i w Turcji, Włoszech bądź Grecji. W przypadku nauki języka francuskiego kolejne edycje kursu mogą odbywać się - poza Francją lub np. Kanadą - również w Tunezji i Maroku. Analogicznie kształcenie w zakresie języka 
angielskiego może być realizowane najpierw w krajach anglojęzycznych, ale też w Indiach czy choćby w Polsce. Kluczem do wyboru miejsca kształcenia w pierwszej kolejności powinien być oczywiście zakres użytkowy nauczanego języka - obcego dla uczącego się. Drugim podstawowym kryterium należy ustanowić społeczno-kulturowe i transgraniczne powiązania, które przesądzają o takim, a nie innym składzie narodowościowym i etnicznym państw będących w kręgu zainteresowania kursanta - z jednej strony tych stanowiących nową życiową przystań dla emigrantów, jak np. wspomniane Szwecja, Niemcy, Francja i Wielka Brytania, z drugiej natomiast tych, które stosownie do wyżej wymienionych zawsze pozostaną kolebką kulturową emigrujących i w których kultura Turków, Serbów, Albańczyków, Pakistańczyków, Tunezyjczyków, Hindusów, Ukraińców czy Polaków będzie najłatwiej dostępna dla uczących się. Poznanie tej kultury z pewnością pozwoli zrozumieć problemy emigrantów i goszczących je narodów.

\section{Optymalny vs utopijny model kształcenia}

Bez gruntownej analizy empirycznej, bazującej nie tylko na danych ilościowych, ale przede wszystkim na materiale jakościowym, trudno jednoznacznie stwierdzić, czy kurs języka obcego w rotacji transgranicznej jest koncepcją utopijną, czy też jednak może przyczynić się do optymalizacji nauczania języków obcych, a wraz z tym do usprawnienia procesu kształtowania kompetencji międzykulturowej uczących się. Pobieżny przegląd danych faktograficznych pozwala stwierdzić, że coraz większa liczba osób pragnących poznać język obcy decyduje się właśnie na uczestnictwo w kursie zagranicznym. Z uwagi na wysokie koszty, są to jednak zwykle kursy krótkoterminowe, o charakterze intensywnym, a więc skoncentrowane przede wszystkim na rozwijaniu typowo komunikacyjnych kompetencji obcojęzycznych, ewentualnie realizowane w kontekście doskonalenia zawodowego. Dla dużej rzeszy Polaków, ale zapewne i wielu innych monolingwalnych nacji, taka forma kształcenia pozostaje poza ekonomicznym zasięgiem, a nawet jeśli się na nią zdecydują, to raczej stanowi ona pojedynczy epizod w ich długoletnim edukacyjnym curriculum. Epizodyczność i elitarny charakter przesądzają zaś o tym, że wybór pada najczęściej, choć zapewne nie zawsze, na kurs zlokalizowany w rodzimym dla danego języka kraju czy regionie, zwykle w jego kulturalnym centrum. Przez to program nauczania międzykulturowego pozostaje ograniczony do minimum, a więc polega na pobieżnym zapoznaniu kursantów z wybranym materialnym i niematerialnym dorobkiem kulturowym rodzimych użytkowników języka. Kursanci czytają więc narodową poezję, słuchają regionalnej muzyki, uczestniczą w projekcjach 
rodzimego kina, zwiedzają okoliczne zabytki. Na zagłębienie się w aspekty rzeczywistej wielo- i międzykulturowości, kreowanej także przez mniejszościowe kultury, religie i języki, pozostaje zazwyczaj niewiele czasu lub po prostu czasu tego nie ma w ogóle - tak przynajmniej należy przypuszczać na podstawie publikowanych założeń programowych dla poszczególnych kursów. O ile na etapie nauki podstawowej taki skrótowy kurs z zakresu międzykulturowości można jeszcze zaakceptować, to w przypadku zaawansowanych poziomów kształcenia jest to już wada znacznej wagi. Można oczywiście argumentować, że dla kursantów szczególnie zainteresowanych omawianą problematyką przewidziano stosowne studia wyższe i będzie to argument słuszny, choć przez wielu uznany zapewne za nadużycie bagatelizujące zainteresowania pasjonatów, którzy na studia nie mogą już sobie pozwolić, jak np. wspomniani seniorzy.

Uwzględniając niezwykle rozbudowaną sieć szkół językowych, a przede wszystkim instytutów języków i kultur narodowych posiadających swoje siedziby oraz przedstawicielstwa partnerskie niemal w każdym cywilizowanym zakątku globu ziemskiego, trudno jednak odrzucić tezę, że przy odpowiednim zaangażowaniu sił i środków, być może przy wsparciu z grantów udzielanych przez organizacje międzynarodowe, można opracować szczegółowy, długoterminowy lub przynajmniej cykliczny program edukacji międzykulturowej realizowany na bazie kursu języka obcego w różnych krajach, w których tego języka się naucza. Nawet jeśli byłby to kurs elitarny, nie można wykluczyć popytu na tego typu ofertę, z której mogliby korzystać np. dyplomaci, mediatorzy międzykulturowi lub właśnie pasjonaci. Jeśli byłaby ona sensownie powiązana z kształceniem uniwersyteckim, także studenci niezwykle dziś popularnych kierunków neofilologicznych czy stosunków międzynarodowych i międzykulturowych zapewne również byliby zainteresowani tą formą kształcenia. Obecnie taki rozszerzony program własnego rozwoju można opracować na własną rękę.

\section{Zakończenie}

Pluralizm języków i kultur, a jednocześnie wynikające z niego zagrożenia i szanse, zupełnie inne niż przed laty, każą odrzucić prosty model kształcenia obcojęzycznej kompetencji komunikacyjnej, która będzie wspomagana powierzchowną, niekiedy wręcz trywialną wiedzą o obcej kulturze historycznie powiązanej z konkretnym obszarem językowym. Tak rozumiana „gotowość do podjęcia dialogu międzykulturowego" może co najwyżej służyć zaspokajaniu celów edukacji początkowej, celów w gruncie rzeczy podstawowych, jak prosta wymiana informacji lub też równie prosta wymiana handlowa. Takie kompetencje stanowią dopiero zalążek kompetencji międzykulturowej, która daleko wykracza poza tę 
wiedzę i te umiejętności, i jest dużo bardziej wyspecjalizowanym narzędziem poznawczym, wyjątkową strategią działania w i wobec wielokulturowości.

Jeżeli celem międzykulturowego dialogu - a tego wykluczyć przecież nie można - będzie nawiązanie głębszej współpracy, która dwóm (lub więcej) stronom interakcji ma przynieść określone korzyści w sferach życia znacznie bardziej skomplikowanych aniżeli wymiana zdań na lotnisku czy zakupy w sklepie z pamiątkami, to nie zawsze, ale zapewne bardzo często, znajomość werbalnego kodu komunikacyjnego oraz podstawowa orientacja na temat właściwości kultury innojęzycznego rozmówcy mogą się okazać niewystarczające. Będzie tak zwłaszcza wówczas, gdy uczącemu się języka obcego przyjdzie się zetknąć z przedstawicielem zupełnie innej kultury niż pierwotnie sądził - np. na podstawie obszaru geograficznego, w którym się znalazł, bądź na podstawie języka, którym ten się posługuje. Brak kompetencji międzykulturowej będzie w takim przypadku skutkował niską efektywnością współpracy lub wręcz jej zerwaniem, niekiedy zaś po prostu niemożnością jej podjęcia. A przecież na skutek rozrostu i intensyfikacji obszarów wielokulturowych, a zatem i obszarów pogranicza kulturowego, do współpracy takiej może i powinno dochodzić coraz częściej.

Dlatego też tak ważne jest poszukiwanie takich miejsc i form nauczania/uczenia się języków obcych, które będą umożliwiały uczącemu się rzeczywisty kontakt z wielo- i międzykulturowością, w różnych jej postaciach i wymiarach. Co więcej, które pozwolą zweryfikować jego kompetencje komunikacyjne w praktyce życia codziennego i nie będą się ograniczały wyłącznie do podawczych metod nauczania bazujących na encyklopedycznym przekazie treści, te bowiem w gruncie rzeczy dawno już mogły ulec dewaluacji. Kurs języka obcego w rotacji transgranicznej - w pełnym wymiarze kompetencyjnym dla większości Polaków raczej elitarny - w założeniach teoretycznych niewątpliwie spełnia te kryteria. O jego realnej efektywności będą jednak przesądzały takie czynniki, jak: merytoryczne przygotowanie i zaangażowanie kadry dydaktycznej, równie merytoryczny i jednocześnie interesujący program kształcąco-wychowawczy, daleko wykraczający poza klasowo-lekcyjny system nauczania/uczenia się, szeroko pojęte zaplecze logistyczne i otoczenie kulturowe stwarzające okazje do międzykulturowych interakcji, a ponadto potencjał, jaki kryje się w uczestnikach kursu. Oczywistym jest również, że warunkiem tej efektywności jest wdrożenie spójnej koncepcji tego typu kursu, uwzględniającej - niezależnie od nauczanego języka - przede wszystkim przedmiotową rotację miejsc, w których jest organizowany, i odpowiadającą temu dywersyfikację oferty kulturalnej obejmującej właśnie specyfikę oraz problemy kultur lokalnych, w tym napływowych.

Choć dla jednych będzie to utopijne rozwiązanie dydaktyczno-wychowawcze, dla innych może się okazać intrygujące, a jednocześnie realne i przynoszące 
pożądane korzyści. Jednak niezależnie od jego oceny i poziomu implementacji w funkcjonujący system edukacji obcojęzycznej i kulturowej, nauczaniu języka obcego w rotacji transgranicznej należy poświęcić więcej uwagi, uczynić je przedmiotem glottodydaktycznych i społeczno-kulturowych badań. Zgromadzony dzięki temu materiał empiryczny z pewnością ułatwiłby zrozumienie współczesnych problemów, jakich w sposób tak zwielokrotniony dostarcza dziś pluralizm języków i kultur. Być może pozwoliłby również niejeden z nich rozwiązać.

\section{BIBLIOGRAFIA}

Bolten, J. 2007. Interkulturelle Kompetenz. Erfurt: Landeszentrale für politische Bildung Thüringen.

Byram, M. 1997. Teaching and assessing intercultural communicative competence. Clevedon: Multilingual Matters.

Rada Europy: Coste, D., North, B., Sheils, J., Trim, J. 2003. Europejski system opisu kształcenia językowego: uczenie się, nauczanie, ocenianie. Warszawa: Wydawnictwo CODN. Tłumaczenie z oryginału: Common European Framework of Reference for Languages: Learning, teaching, assessment. Council of Europe, 2001.

Jaroszewska, A. 2013. Nauczanie języków obcych seniorów w Polsce. Analiza potrzeb i możliwości w aspekcie międzykulturowym. Kraków: Oficyna Wydawnicza „Impuls”.

Jaroszewska, A. 2015: „Die Entwicklung interkultureller Kompetenz - die Kehrseite der Medaille am Beispiel des polnischen Bildungssystems". (w) Literatur und Interkulturalität im Fremdsprachenunterricht am Anfang des 21. Jahrhunderts. Schriftenreihe: „Lingua. Fremdsprachenunterricht in Forschung und Praxis”. Band 32. (red. J. Kic-Drgas). Hamburg: Verlag Dr. Kovac, str. 133-150.

\section{Netografia}

http://www.alliance-francaise.pl [DW 31.08.2015].

http://www.britishcouncil.pl [DW 31.08.2015].

http://www.cervantes.es/default.htm [DW 31.08.2015].

https://www.goethe.de/de/index.html [DW 31.08.2015].

http://www.iicvarsavia.esteri.it/IIC_Varsavia [DW 31.08.2015].

http://www.inthouse.pl/kursy-jezykowe-za-granica [DW 31.08.2015].

http://www.kursyjezykowe.net/index.php [DW 31.08.2015].

http://www.kursy-jezykowe-za-granica.pl [DW 31.08.2015].

http://www.lexis.edu.pl/kursyjezykowezagranica.htm [DW 31.08.2015].

http://www.obozyjezykowe.com.pl [DW 31.08.2015].

http://www.podrozejezykowe.pl [DW 31.08.2015].

http://www.pushkin.institute [DW 31.08.2015].

http://www.warszawa.oei.org.pl [DW 31.08.2015].

http://www.wyjazdy-jezykowe.pl [DW 31.08.2015]. 